Contents List available at VoLKSON PRESS
Medical and Pharmaceutical Research (MPR)
DOI : http://doi.org/10.26480/wcmpr.01.2018.29.31
Journal Homepage: http://www.topicsonbiomed.com//

\title{
CHINESE ELDERLY HEALTH BEHAVIOR AND ORAL HEALTH
}

YeJiao Luo, RenGuo Gong*

The First Affiliated Hospital of Chengdu Medical College

*Corresponding Author Email: 463445624@qq.com

This is an open access article distributed under the Creative Commons Attribution License, which permits unrestricted use, distribution, and reproduction in any medium, provided the original work is properly cited

\section{ARTICLE DETAILS}

\section{ARTICLE HISTORY:}

Received 2nd January 2018

Accepted 2nd January 2018

Available online $3^{\text {rd }}$ January 2018

\section{KEYWORDS:}

Elderly, health behavior, oral health, morbidity.

\section{ABSTRACT}

Objective: To statistically analyze the coupling relationship between the health behaviors of Chinese elderly and oral health. Methods: According to the age group selected by the WHO Oral Health Survey Base-Wood Method, we selected the resident population aged 65-74 in a community as the survey subjects, and randomly selected 120 65-74-year-olds at a 1: 1 ratio Issue questionnaire. Statistically significant habits and non-good health habits of oral disease incidence statistical analysis, the difference was significant $(\mathrm{P}<0.05)$, with statistical significance. Conclusion: Good health behavior can reduce the probability of occurrence of oral diseases.

\section{INTRODUCTION}

With the increase of the elderly population, our country has entered the aging society and the health problems of the elderly people are increasingly arousing public concern. Improving the health status of the elderly, extending the life expectancy of the elderly and improving their quality of life have become an important part of raising the overall physical fitness and increasing the life expectancy of the people. Oral health plays an important role in extending the health and life expectancy of people and in improving overall quality of life. Therefore, the oral health of the elderly is even more important. Oral cavity as an important part of the body, exercise many functions [1].

Their health also directly affects the general health. After entering the elderly, people are weakened and even decline in their normal oral physiological function due to aging. On the other hand, due to the invasion of oral diseases, especially the effects of periodontal diseases on oral health, accompanied by some of the symptoms, such as pain, loose teeth, etc., will have a great impact on the elderly's normal life. Oral health and food digestion and absorption, but also with the health of the body has a close relationship [2]. In our country, a considerable proportion of elderly people pay much less attention to oral hygiene than scientific requirements. The prevalence of oral health problems among older persons and traditional attitudes and habits that do not pay attention to oral hygiene [3].

Therefore, maintaining good oral health is not only important for the prevention of oral diseases, but also an important part of modern civilized life. Oral health, as an integral part of general health and quality of life, plays an important role in prolonging the life of human health and improving overall quality of life [4]. With the medical attention to the quality of life, oral health and quality of life are more and more people's attention.

\section{MATERIALS AND METHODS}

\subsection{Survey target}

According to the age group determined by the WHO Oral Health Survey Base Method (Version 1), the respondents selected the resident population aged 65-74 in a community as the survey object, the age of the survey month prevail, according to the 3rd National Oral Health Epidemiological sampling survey program requirements, using multi- stage stratified equal-capacity random sampling method. According to the ratio of 1: 1 men and women randomly selected 120 65-74-year old's.

\subsection{Findings}

120 questionnaires were actually distributed, and 120 questionnaires were collected. In addition, 112 questionnaires were removed from the incomplete or unqualified questionnaires, and the effective recovery rate was $88 \%$.

\subsection{Sampling method}

First consult the relevant literature results, sample size calculation formula $\mathrm{N}=\mathrm{kq} / \mathrm{p}$ to determine the sample size. Then stratified cluster random sampling method, randomly selected.

\subsection{Design stage}

First of all, on the basis of extensive reference to the literature and listening to the opinions of relevant experts, the questionnaire was designed in strict accordance with the methods and principles of the questionnaire design. The questionnaire was developed with reference to the Third National Questionnaire on Oral Health and was repeatedly revised in the course of pre-trial studies and found to be of use in the investigation of oral health in the elderly. Ensure the validity and reliability of the questionnaire.

The contents of the questionnaire are as follows:

(1) General situation: the name of the respondent, gender, birth date and schooling years;

(2) Habits: smoking situation; drinking and drinking tea situation;

(3) Medical needs: the last time to see the tooth from the present;

(4) Family economic status: the total income of a family living together in the past year;

(5) Oral hygiene habits: whether there is a regular clean tooth. Regular cleaning of teeth means cleaning the teeth with a toothbrush or dental floss at least once a day.

\subsection{Implementation phase}

With the help of the selected community sub district offices and neighborhood committees, population statistics of the elderly over 65-74 
years of age in selected communities are conducted and then household surveys are conducted on a household-by-household basis. During the investigation, the respondents were asked to read the informed consent form, explain the purpose and significance of the study to the respondents, and ensure the confidentiality of the investigation contents. After obtaining the consent of the respondents, the project investigation will be conducted. For the elderly who cannot complete the survey on their own, informed family members assist in providing the content.

\subsection{Data processing stage}

Review the survey questionnaires one by one, remove the questionnaire does not meet the requirements. Ask epidemiologists to validate statistical methods.

\section{STATISTICAL ANALYSIS AND RESULT ANALYSIS}

The first summary of the data, review, sorting, coding and quantification, and then enter the Excel worksheet, then SPSS12.0 software package for statistical description and analysis. Descriptive Statistics-Frequencies Crosstabs and other processes of SPSS software were used to describe the general information of the respondents, oral health knowledge, oral health beliefs, oral health behaviors and so on. Using SPSS software Multiple Response Tables to analyze the way to obtain the health knowledge of the respondents. Statistical analysis SPSS12.0 software package for statistical analysis of survey data, measurement data, said that the use of two-t test, count data expressed as a percentage, using the test. $\mathrm{P}<0.05$ for the difference was statistically significant. As shown in Table 1.

Table 1: Data statistics

\begin{tabular}{|c|c|c|c|c|c|c|c|}
\hline \multirow{2}{*}{\multicolumn{2}{|c|}{$\begin{array}{c}\text { Oral } \\
\text { health } \\
\text { behavior }\end{array}$}} & \multicolumn{2}{|c|}{ Male } & \multicolumn{2}{|c|}{ Female } & \multirow[b]{2}{*}{$\begin{array}{c}\text { Number } \\
\text { of } \\
\text { people }\end{array}$} & \multirow{2}{*}{$\begin{array}{l}\text { Perc } \\
\text { enta } \\
\text { ge } \\
\%)\end{array}$} \\
\hline & & $\begin{array}{l}\text { Number } \\
\text { of } \\
\text { people }\end{array}$ & $\begin{array}{c}\text { perce } \\
\text { ntage } \\
(\%)\end{array}$ & $\begin{array}{c}\text { Number } \\
\text { of } \\
\text { people }\end{array}$ & $\begin{array}{c}\text { perce } \\
\text { ntage } \\
(\%)\end{array}$ & & \\
\hline & $\begin{array}{c}\text { Brush } \\
\text { your } \\
\text { teeth } \\
\text { twice } \\
\text { a day } \\
\text { and } \\
\text { above }\end{array}$ & 32 & 42 & 36 & 48 & & \\
\hline & $\begin{array}{c}\text { Brush } \\
\text { each } \\
\text { time } \\
3 \text { min } \\
\text { and } \\
\text { above }\end{array}$ & 22 & 29 & 30 & 40 & & \\
\hline $\mathrm{G}$ & $\begin{array}{l}\text { Use } \\
\text { fluori } \\
\text { de } \\
\text { toothp } \\
\text { aste }\end{array}$ & 30 & 40 & 28 & 37 & & \\
\hline $\begin{array}{l}0 \\
\text { o } \\
\text { d }\end{array}$ & $\begin{array}{l}\text { Vertic } \\
\text { al } \\
\text { brush } \\
\text { metho } \\
\text { d }\end{array}$ & 18 & 24 & 17 & 23 & 75 & 67 \\
\hline $\begin{array}{l}\text { o } \\
\text { u } \\
\text { p }\end{array}$ & $\begin{array}{l}\text { Brush } \\
\text { ing } \\
\text { your } \\
\text { teeth } \\
\text { before } \\
\text { going } \\
\text { to bed }\end{array}$ & 21 & 28 & 30 & 40 & & \\
\hline & $\begin{array}{l}\text { Tooth } \\
\text { brush } \\
\text { every } \\
\text { three } \\
\text { month } \\
\text { s }\end{array}$ & 15 & 20 & 32 & 42 & & \\
\hline & $\begin{array}{l}\text { Regul } \\
\text { ar } \\
\text { inspec } \\
\text { tion } \\
\text { and } \\
\text { cleani } \\
\text { ng }\end{array}$ & 12 & 16 & 20 & 27 & & \\
\hline
\end{tabular}

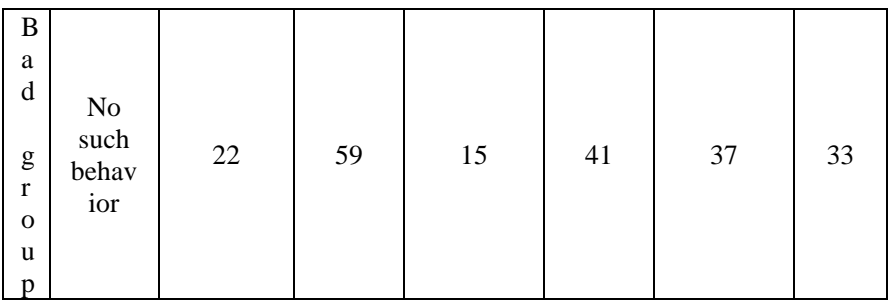

\section{RESULTS}

After investigation and statistics, the incidence of elderly patients with oral diseases among 75 healthy people and 33 elderly people with poor health was statistically analyzed. There was no significant difference between different groups $(\mathrm{P}>0.05)$.

\subsection{Comparison of gingival bleeding in two groups of people}

After investigation and statistics, good group of 75 elderly people, bleeding gums in 12 cases, the incidence was $16 \%$. In the 33 cases of poor group, 22 cases of bleeding gums, the incidence was $67 \%$. And there was no significant difference between the two groups in the incidence of gingival bleeding. $(\mathrm{P}>0.05)$, see Table 2 .

Table 2: Different groups of elderly patients with gingival bleeding compared the incidence (n)

\begin{tabular}{|l|l|l|l|}
\hline Group & $\begin{array}{l}\text { Number } \\
\text { of cases }\end{array}$ & $\begin{array}{l}\text { Bleeding } \\
\text { gums }\end{array}$ & Incidence \\
\hline $\begin{array}{l}\text { Good } \\
\text { group }\end{array}$ & 75 & 12 & $16 \%$ \\
\hline $\begin{array}{l}\text { Bad } \\
\text { group }\end{array}$ & 33 & 22 & $67 \%$ \\
\hline P & $>0.05$ \\
\hline
\end{tabular}

\subsection{Two groups of people in the case of dental calculus contrast}

After investigation and statistics, good group of 75 elderly, calculus in 14 cases, the incidence was $19 \% .33$ cases of poor elderly group, 21 cases of dental calculus, the incidence was $64 \%$. There was no significant difference in the incidence of calculus between different groups. ( $P>$ $0.05)$, see Table 3

Table 3: The incidence of dental calculus in different groups of elderly (n)

\begin{tabular}{|l|l|l|l|}
\hline Group & $\begin{array}{l}\text { Number } \\
\text { of cases }\end{array}$ & $\begin{array}{l}\text { Bleeding } \\
\text { gums }\end{array}$ & Incidence \\
\hline $\begin{array}{l}\text { Good } \\
\text { group }\end{array}$ & 75 & 14 & $19 \%$ \\
\hline $\begin{array}{l}\text { Bad } \\
\text { group }\end{array}$ & 33 & 21 & $64 \%$ \\
\hline P & $>0.05$ \\
\hline
\end{tabular}

4.3 Comparison of periodontal pockets between two groups of people

After investigation, in the good group of 75 elderly, 18 cases of periodontal pocket, the incidence was $24 \% .33$ cases of poor group of elderly, periodontal pocket in 25 cases, the incidence was $64 \%$. There was no significant difference in the rate of periodontal pocket between different groups. ( $P>0.05)$, see Table 4.

Table 4: Different groups of elderly patients with periodontal pocket incidence (n)

\begin{tabular}{|l|l|l|l|}
\hline Group & Number of cases & $\begin{array}{l}\text { Bleeding } \\
\text { gums }\end{array}$ & Incidence \\
\hline $\begin{array}{l}\text { Good } \\
\text { group }\end{array}$ & 75 & 18 & $24 \%$ \\
\hline $\begin{array}{l}\text { Bad } \\
\text { group }\end{array}$ & 33 & 25 & $76 \%$ \\
\hline P & & $>0.05$ \\
\hline
\end{tabular}

\section{CONCLUSIONS}

Old age oral disease has become a serious social problem in our country. With the population aging, more and more elderly patients come to the 
dentistry clinic. The prevalence of dental diseases in the elderly has indeed become an important factor affecting the quality of life and health. Therefore, understanding their oral health beliefs, behaviors and knowledge of oral health knowledge can not only provide the necessary information for the prevention and control of dental diseases in the community, but also enable clinicians to take targeted dental prevention and treatment measures.

Oral health education for the elderly is a bridge between the aspirations of the elderly to effectively maintain oral health and the ways in which they can be truly controlled and used to prevent health problems. The popularization of oral health knowledge is the best way to promote oral health behavior. The simplest and most important method for elderly patients to care for their teeth and gums is to brush their teeth and maintain good oral health habits, playing a decisive role in the prevention and care of oral diseases.

\section{REFERENCES}

[1] Xiaoqiu, Q. 2008. The third national oral health epidemiological sampling survey [M]. Beijing: People's Medical Publishing House, 7173 .

[2] Xudong, L., Yan, F.F. 2015. Elderly oral health guidance effect analysis [J]. Zhejiang Preventive Medicine, 27 (8), 853-855.

[3] Li-kun, Z. 2015. Analysis on the effects of health education on oral health in the elderly [J]. Chinese Health Industry, 12 (30), 93-95.

[4] Chunxiao, W., Qi, Z., Yang, Y. 2015. Preventive oral hygiene behavior of adults and the elderly in China [J]. Chinese Journal of Public Health, 31 (2), 129-132. 